\title{
PENGARUH BI RATE, INFLASI, NILAI TUKAR RUPIAH, PDB PERKAPITA DAN JUMLAH UANG BEREDAR TERHADAP PERMINTAAN REKSA DANA SAHAM TAHUN $2013-2017$
}

\section{MANAJEMEN KEUANGAN}

\author{
Ade Risdiana Pratiwi ${ }^{1)}$, Sri Murdiati ${ }^{2)}$, Yuniarti Herwinarni ${ }^{3)}$ \\ Email : aderisdiana.pratiwi01@gmail.com \\ Fakultas Ekonomi dan Bisnis \\ Universitas Pancasakti Tegal
}

\begin{abstract}
Abstrak
Tujuan Penelitian adalah untuk menganalisis pengaruh BI Rate, Inflasi, Nilai Tukar Rupiah, PDB Perkapita, dan Jumlah Uang Beredar terhadap Permintaan Reksa Dana Saham 2013-2017 secara parsial dan secara simultan. Jenis data yang digunakan adalah data sekunder berupa data kuartalan. Metode pengumpulan data dalam penelitian ini adalah dokumentasi dengan pengambilan sampel berdasarkan teknik Purposive Sampling. Metode analisis data menggunakan uji asumsi klasik, uji regresi linier berganda, uji $t$, uji $F$, serta analisis koefisien determinasi. Hasil penelitian menunjukan bahwa Secara parsial variabel BI Rate mempunyai pengaruh negatif dan signifikan terhadap Permintaan Reksa Dana Saham. Secara parsial variabel Inflasi mempunyai pengaruh positif dan tidak signifikan terhadap Permintaan Reksa Dana Saham. Secara parsial variabel Nilai Tukar Rupiah mempunyai pengaruh negatif dan tidak signifikan terhadap Permintaan Reksa Dana Saham. Secara parsial variabel PDB Perkapita mempunyai pengaruh negatif dan signifikan terhadap Permintaan Reksa Dana Saham. Secara parsial variabel Jumlah Uang Beredar mempunyai pengaruh positif dan tidak signifikan terhadap Permintaan Reksa Dana Saham. Secara simultan variabel BI Rate, Inflasi, Nilai Tukar Rupiah, PDB Perkapita dan Jumlah Uang Beredar memiliki pengaruh signifikan terhadap Permintaan Reksa Dana Saham.
\end{abstract}

Kata kunci : Reksa Dana Saham, BI Rate, Inflasi, Nilai Tukar Rupiah, PDB Perkapita, Jumlah Uang Beredar, Permintaan.

\begin{abstract}
The objective of the study was to analyze the effect of BI Rate, Inflation, Rupiah Exchange Rate, Per Capita GDP, and Total Money Supply to Mutual Fund Fund Request 2013-2017 partially and simultaneously. The type of data used is secondary data in the form of quarterly data. Data collection method in this research is documentation with sampling based on Purposive Sampling technique. Methods of data analysis using the classical assumption test, multiple linear regression test, $t$ test, $F$ test, and coefficient of determination analysis. The result of the research shows that partially variable of BI Rate has negative and significant influence to stock fund equity demand. Partially Inflation variable has a positive and insignificant effect on the Request of Equity Fund In partial variable Rupiah Exchange Rate has a negative and insignificant effect on Demand of Investment Fund In partial variable GDP Perkapita have a negative and significant influence on the Demand of Mutual Fund. Partially, the variable of Money Supply has positive and insignificant effect on the Request of Mutual Fund. Simultaneously, the variables of BI Rate, Inflation, Rupiah Exchange Rate, Per Capita GDP and Total Money Supply have a significant influence on the Demand of Mutual Fund.
\end{abstract}

Keywords: Equity Fund, BI Rate, Inflation, Rupiah Exchange Rate, GDP Per Capita, Money Supply, Demand. 


\section{PENDAHULUAN}

Pasar modal merupakan pilihan alternatif investasi yang dapat menghasilkan keuntungan optimal bagi investor. Pada dasarnya pasar modal (capital market) merupakan pasar untuk berbagai instrumen keuangan jangka panjang yang bisa diperjualbelikan, baik dalam bentuk uang maupun modal sendiri.

Reksa dana (Mutual Fund) merupakan suatu kumpulan dana dari masyarakat, pihak pemodal atau pihak investor untuk kemudian dikelola oleh Manajer Investasi dan diinvestasikan pada berbagai jenis portofolio investasi efek atau produk keuangan lainnya. Dalam penelitian ini, penulis menggunakan reksa dana saham sebagai variabelnya. Berikut ini penulis menyajikan tabel perkembangan reksa dana saham selama lima tahun terakhir.

\section{Tabel 1}

Perkembangan Industri Reksa Dana Saham Periode 2013-2017

\begin{tabular}{|c|c|c|}
\hline TAHUN & $\begin{array}{c}\text { JUMLAH } \\
\text { REKSA DANA } \\
\text { SAHAM }\end{array}$ & $\begin{array}{c}\text { Nilai Aktiva } \\
\text { Bersih } \\
\text { (NAB) }\end{array}$ \\
\hline 2013 & 110 & Rp. 77,99 trilyun \\
\hline 2014 & 133 & Rp. 92,24 trilyun \\
\hline 2015 & 161 & Rp. 101,31 trilyun \\
\hline 2016 & 209 & Rp. 109,70 trilyun \\
\hline 2017 & 240 & Rp. 111,19 trilyun \\
\hline
\end{tabular}

Sumber : e-monitoring OJK (Data

diolah, 2018)

Pada penelitian ini, peneliti ingin menganalisis pengaruh variabel makroekonomi dengan indikator diantaranya adalah BI Rate, Inflasi, Nilai Tukar Rupiah, PDB Perkapita dan Jumlah Uang Beredar Terhadap Permintaan Reksa Dana Saham. Hal ini dapat dilihat dari teori-teori variabel makroekonomi tersebut terhadap Nilai Aktiva Bersih (NAB) Reksa Dana Saham.

Sebagaimana yang telah dijelaskan pada landasan teori, tentang bagaimana hubungan setiap indikator-indikator tersebut terhadap permintaan reksa dana saham dapat dijabarkan sebagai berikut :

Ketika suku bunga bank sentral diturunkan, reksa dana yang berinvestasi pada obligasi seperti reksa dana pasar uang, reksa dana pendapatan tetap dan reksa dana campuran akan diuntungkan dan sebaliknya. Untuk saham, dampak suku bunga umumnya tidak langsung. Secara teori, penurunan tingkat suku bunga akan menyebabkan bunga tabungan dan deposito di perbankan menjadi tidak menarik. Masyarakat akan mencari alternatif lain dengan imbal hasil yang lebih tinggi yaitu pasar modal.

Meningkatnya permintaan akibat penurunan bunga akan menyebabkan kenaikan harga saham dan sebaliknya. Begitu juga untuk reksa dana saham, semakin banyaknya masyarakat yang bergabung dengan pasar modal, maka permintaan akan reksa dana saham juga akan meningkat mengingat reksa dana adalah alternatif pilihan investasi yang baik dan reksa dana jenis saham merupakan jenis reksa dana yang paling banyak peminatnya.

Ketika terjadi kenaikan tingkat inflasi maka harga barang dan jasa akan semakin tinggi, biaya produksi perusahaan pun juga akan meningkat. Sehingga, apabila biaya produksi perusahaan meningkat, namun outputnya tetap, laba yang didapatkan perusahaan tentunya juga akan berkurang, dan berpengaruh terhadap keuntungan yang didapatkan investor nantinya. Dalam hal ini, dapat dikatakan bahwa ketika inflasi meningkat, maka resiko untuk berinvestasi pada reksa dana saham juga semakin meningkat. Perkembangan inflasi merupakan salah satu faktor yang menjadi perhatian manajer investasi dalam pertimbangan, khususnya dengan perkembangan nilai aktiva bersih (NAB) reksa dana. Kenaikan inflasi ini akan meningkatkan NAB reksa dana yang berpengaruh pada besar kecilnya tingkat permintaan reksa dana saham.

Dalam apresiasi rupiah terhadap mata uang dollar AS, masyarakat bisa melihat bahwa mata uang rupiah sebagai salah satu indikator makroekonomi negara mengalami perbaikan. Hal ini akan meningkatkan permintaan ekspetasi dalam berinvestasi sehingga dapat meningkatkan permintaan terhadap reksa dana saham, akibatnya nilai aktiva bersih (NAB) reksa dana saham akan meningkat dan sebaliknya 
Dengan meningkatnya jumlah pendapatan tetap masyarakat, maka masyarakat cenderung akan menanamkan uangnya pada instrumen investasi, reksa dana merupakan alternatif investasi yang bisa dengan mudah di kendalikan walau dengan keterbatasan waktu dan biaya. Reksa dana saham merupakan reksa dana yang memiliki porsi paling banyak pemiliknya. Bila perekonomian makin maju, porsi penggunaan uang kartal makin sedikit, digantikan uang giral atau near money. Ketika jumlah uang beredar dimasyarakat semakin bertambah sehingga ekspektasi harga-harga barang dan jasa akan ikut naik (inflasi) mengakibatkan tingkat suku bunga deposito dalam perekonomian menurun, dari peristiwa tersebut menyebabkan masyarakat lebih memilih untuk menginvestasikan dananya dipasar modal dengan harapan akan memperoleh keuntungan yang lebih besar sehingga akan berdampak pada peningkatan permintaan saham di pasar modal (Budiono, 2005:95-96 dalam jurnal Akbar Maulana, 2013).

Jumlah uang beredar mempengaruhi Nilai Aktiva Bersih (NAB) reksa dana. Pada saat terjadi kenaikan jumlah uang beredar, masyarakat dianggap memiliki proporsi lebih untuk berinvestasi sehingga permintaan instrumen investasi saham mengalami kenaikan yang berarti akan meningkatkan NAB reksa dana saham, dan sebaliknya.

\section{PERUMUSAN MASALAH}

Berdasarkan uraian penjelasan latar belakang diatas, maka permasalahan yang dikaji dalam penelitian ini adalah sebagai berikut :

2.1. Apakah BI Rate berpengaruh terhadap permintaan reksa dana saham tahun 2013-2017?

2.2. Apakah inflasi berpengaruh terhadap permintaan reksa dana saham tahun 2013-2017?

2.3. Apakah nilai tukar rupiah berpengaruh terhadap permintaan reksa dana saham tahun 2013-2017?

2.4. Apakah PDB Perkapita berpengaruh terhadap permintaan reksa dana saham tahun 2013-2017?

2.5. Apakah jumlah uang beredar berpengaruh terhadap permintaan reksa dana saham tahun 2013-2017 ?

2.6. Apakah BI Rate, inflasi, nilai tukar rupiah, PDB perkapita, dan jumlah uang beredar secara simultan berpengaruh terhadap permintaan reksa dana saham tahun 2013-2017 ?

\section{TUJUAN PENELITIAN}

Adapun tujuan dari penelitian ini adalah sebagai berikut :

3.1. Untuk menganalisis pengaruh BI Rate terhadap permintaan reksa dana saham di Indonesia selama periode tahun penelitian

3.2. Untuk menganalisis pengaruh inflasi terhadap permintaan reksa dana saham di Indonesia selama periode tahun penelitian

3.3. Untuk menganalisis pengaruh nilai tukar rupiah terhadap permintaan reksa dana saham di Indonesia selama periode tahun penelitian

3.4. Untuk menganalisis pengaruh PDB perkapita terhadap permintaan reksa dana saham di Indonesia selama periode tahun penelitian

3.5. Untuk menganalisis pengaruh jumlah uang beredar terhadap permintaan reksa dana saham di Indonesia selama periode tahun penelitian

3.6. Untuk menganalisis pengaruh BI Rate, inflasi, nilai tukar rupiah, PDB perkapita, dan jumlah uang beredar secara simultan berpengaruh terhadap permintaan reksa dana saham selama periode tahun penelitian.

\section{KERANGKA BERPIKIR DAN HIPOTESIS PENELITIAN \\ 4.1 Kerangka Berpikir}

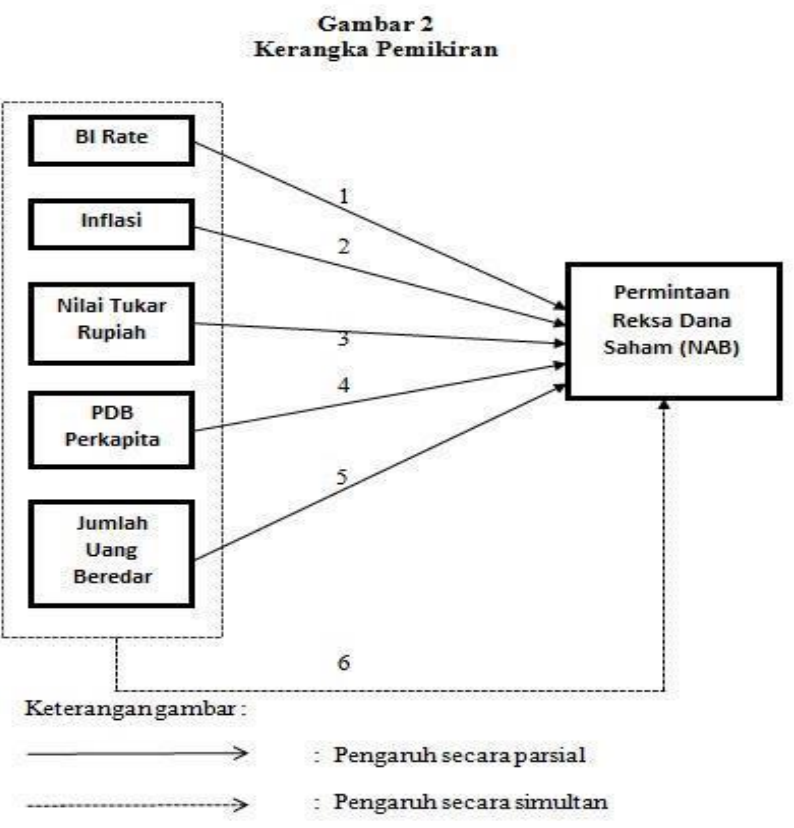




\subsection{Hipotesis Penelitian}

H1. BI Rate berpengaruh terhadap permintaan reksa dana saham tahun 2013-2017

H2. Inflasi berpengaruh terhadap permintaan reksa dana saham tahun 2013-2017

H3. Nilai Tukar Rupiah berpengaruh terhadap permintaan reksa dana saham tahun 2013-2017

H4. PDB Perkapita berpengaruh terhadap permintaan reksa dana saham tahun 2013-2017

H5. Jumlah Uang Beredar berpengaruh terhadap permintaan reksa dana saham tahun 20132017

H6. BI Rate, Inflasi, Nilai Tukar Rupiah, PDB Perkapita, dan Jumlah Uang Beredar secara bersama-sama berpengaruh terhadap permintaan reksa dana saham tahun 2013-2017

\section{METODE PENELITIAN}

\subsection{Pemiliihan Metode}

Metode penelitian yang digunakan dalam penelitian ini adalah metode penelitian kuantitatif. Penelitian ini menggunakan tipe penelitian deskriptif yaitu membahas masalah berupa fakta-fakta saat ini dari suatu populasi, tujuannya untuk menjawab pertanyaan terkait current status dari subyek yang diteliti.

5.2. Populasi dan Sampel Populasinya adalah Reksa

Dana Saham yang tercatat di Otoritas Jasa Keuangan (OJK) selama periode penelitian yaitu tahun 2013-2017 berjumlah 40 reksa dana saham. Sampel dalam penelitian ini adalah reksa dana saham yang terdaftar di OJK yang diambil dengan menggunakan metode Purposive Sampling. Kriteria-kriteria tersebut adalah sebagai berikut :

a. Reksa dana yang tercatat dan masih aktif selama periode waktu penelitian.

b. Reksa dana bukan termasuk reksa dana syariah

c. Merupakan kategori reksa dana saham d. Reksa dana saham yang memiliki data yang lengkap untuk diolah peneliti

e. Reksa dana yang memiliki Nilai Aktiva Bersih (NAB) tinggi.

Dari penentuan kriteria-kriteria tersebut, maka penulis menentukan jumlah sampel reksa dana yang dapat digunakan adalah sebanyak 10 reksa dana saham.

\subsection{Analisis Data dan Uji Hipotesis a.}

a. Uji Asumsi Klasik yang meliputi uji normalitas, uji multikolinieritas, uji autokorelasi, dan uji heterokedastisitas.

b. Analisis Regresi Berganda

c. Uji Parsial (Uji t) dan Uji Simultan (Uji F)

d. Analisis Koefisien Determinasi

\section{HASIL DAN PEMBAHASAN}

6.1. Uji Asumsi Klasik

a. Uji Normalitas

Gambar 3

Grafik Histogram Uji Normalitas

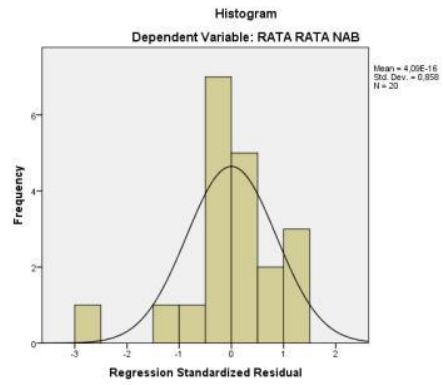

Grafik

Normal P-P Plot Of Regression

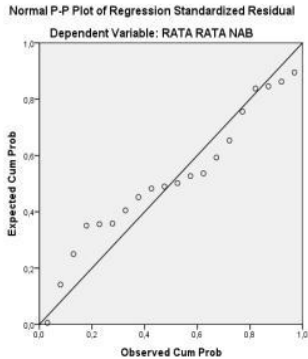

Dari grafik histogram diatas, dapat disimpulkan bahwa residual data berdisitribusi normal karena grafik tersebut berbentuk lonceng. Demikian juga dengan grafik normal $p-p$ plot of 
regression standardized residual menunjukan bahwa plot data menyebar di sekitar dan mengikuti garis diagonal. Dapat disimpulkan bahwa model regresi memenuhi asumsi normalitas.

\section{b. Uji Multikolinieritas}

Tabel 2

\section{Hasil Uji Multikolinieritas}

\begin{tabular}{|c|c|c|}
\hline \multicolumn{3}{|c|}{ Coefficients $^{\mathbf{a}}$} \\
\hline \multirow[b]{2}{*}{ Model } & \multicolumn{2}{|c|}{ Collinearity Statistics } \\
\hline & Tolerance & VIF \\
\hline 1 (Constant) & & \\
\hline BI RATE &, 371 & 2,699 \\
\hline INFLASI &, 540 & 1,853 \\
\hline NTR & , 197 & 5,078 \\
\hline PDB & ,204 & 4,900 \\
\hline ЈUB &, 558 & 1,791 \\
\hline
\end{tabular}

Dependent Variable: NAB

Dari tabel diatas, hasil uji multikolinieritas terlihat bahwa nilai tolerance variabel BI Rate $\left(X_{1}\right)$ sebesar 0,371, variabel Inflasi $\left(\mathrm{X}_{2}\right)$ sebesar 0,540 , variabel Nilai Tukar Rupiah $\left(\mathrm{X}_{3}\right)$ sebesar 0,197, variabel PDB Perkapita $\left(\mathrm{X}_{4}\right)$ sebesar 0,204, dan variabel Jumlah Uang Beredar (X5) sebesar 0,558. Semua variabel independen dalam penelitian ini mempunyai nilai toleransi $\leq \quad 0,6$. Sedangkan VIF (Variance Inflation Factor) terdapat nilai vari abel BI Rate $\left(\mathrm{X}_{1}\right)$ sebesar 2,699, variabel Inflasi $\left(\mathrm{X}_{2}\right)$ sebesar 1,853 , variabel Nilai Tukar Rupiah $\left(\mathrm{X}_{3}\right)$ sebesar 5,078, variabel PDB Perkapita $\left(\mathrm{X}_{4}\right)$ sebesar 4,900 , dan variabel Jumlah Uang Beredar (Xs) sebesar 1,791. Dengan demikian diperoleh nilai VIF > 10 . Dapat disimpulkan bahwa tidak ada multikolinieritas antar variabel, dan berdasarkan nilai tolerance dan nilai VIF dari hasil diatas menunjukan bahwa model regresi yang dibuat layak untuk dipergunakan dalam penelitian c. Uji Autokorelasi

Tabel 7

Hasil Uji Autokorelasi

Runs Test

\begin{tabular}{|c|c|}
\hline \multicolumn{2}{|c|}{ Runs Test } \\
\hline & $\begin{array}{c}\text { Unstandardized } \\
\text { Residual } \\
\end{array}$ \\
\hline Test Value ${ }^{a}$ & $-5,23420$ \\
\hline Cases $<$ Test Value & 10 \\
\hline Cases >= Test Value & 10 \\
\hline Total Cases & 20 \\
\hline Number of Runs & 8 \\
\hline Z & $-1,149$ \\
\hline Asymp. Sig. (2-tailed) & 251 \\
\hline
\end{tabular}

Berdasarkan tabel diatas menunjukan bahwa nilai Asymp Sig. (2-tailed) sebesar $0,251>0,05$. Maka dapat disimpulkan tidak ada autokorelasi dalam model regresi.

\section{d. Uji Heteroskedastisitas}

Gambar 4

Scatterplot Uji Heteroskedastisitas

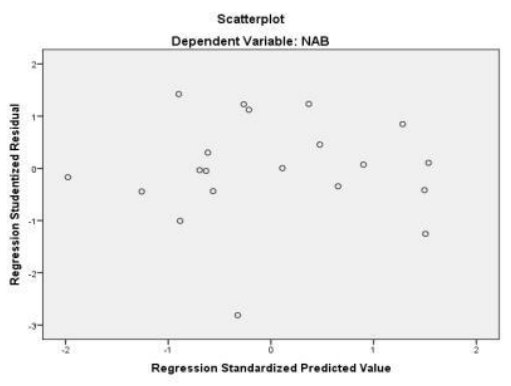

Berdasarkan gambar diatas, terlihat titik-titik menyebar secara acak atau tidak membentuk pola tertentu yang jelas atau teratur, serta tersebar baik diatas maupun dibawah angka 0 pada sumbu Y. Hal ini berarti tidak terjadi gejala heteroskedastisitas. 


\subsection{Analisis Regresi Berganda}

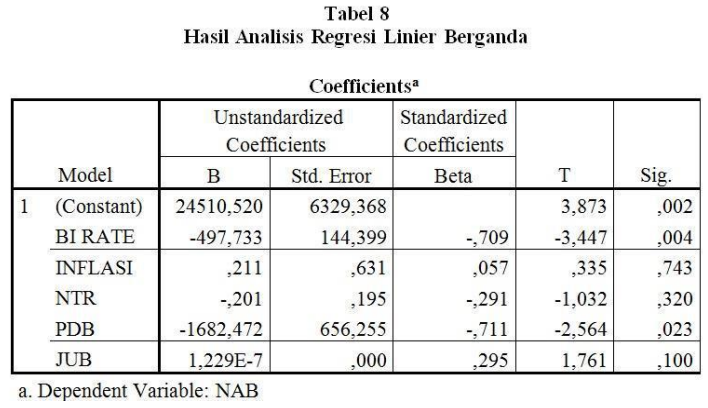

Berdasarkan hasil pengolahan data diatas, dapat diperoleh persamaan regresi linier berganda, sebagai berikut :

$Y=24510,520-497,733 X_{1}+$

$0,211 X_{2}-0,201 X_{3}-1682,472 X_{4}+$ $1,2290000000 X_{5}+e$

Dimana :

Y = NAB Reksa Dana Saham

$\mathrm{X}_{1}=\mathrm{BI}$ Rate

$\mathrm{X}_{2}=$ Inflasi

$\mathrm{X}_{3}=$ Nilai Tukar Rupiah

$\mathrm{X}_{4}=$ PDB Perkapita

$\mathrm{X}_{5}=$ Jumlah Uang Beredar

$\mathrm{e} \quad=$ eror

Sehingga dapat disimpulkan bahwa :

a. Konstanta $(\alpha)$ sebesar 24510,52 yang artinya jika BI Rate, Inflasi, Nilai Tukar Rupiah, PDB Perkapita, dan Jumlah Uang Beredar sebesar 0 maka Nilai Aktiva Bersih Reksa Dana Saham sebesar Rp. 24510,52.

b. Koefisien regresi BI Rate bertanda negatif yaitu sebesar 497,733 yang artinya jika variabel independen lainnya nilainya tetap dan pertumbuhan BI Rate mengalami penurunan sebesar $1 \%$ maka Nilai Aktiva Bersih akan mengalami kenaikan sebesar Rp. 497,733. Begitu juga sebaliknya, jika pertumbuhan BI Rate mengalami kenaikan sebesar $1 \%$ maka Nilai Aktiva Bersih akan mengalami penurunan sebesar Rp. 497,733.

c. Koefisien regresi Inflasi bertanda positif yaitu sebesar 0,211 yang artinya jika variabel independen lainnya nilainya tetap dan pertumbuhan Inflasi mengalami kenaikan sebesar $1 \%$ maka Nilai
Aktiva Bersih akan mengalami kenaikan sebesar Rp. 0,211. Begitu juga sebaliknya, jika pertumbuhan Inflasi mengalami penurunan $1 \%$ maka Nilai Aktiva Bersih akan mengalami penurunan sebesar Rp. 0,211.

d. Koefisien regresi Nilai Tukar Rupiah bertanda negatif yaitu sebesar - 0,201 yang artinya jika variabel independen lainnya nilainya tetap dan pertumbuhan Nilai Tukar Rupiah mengalami penurunan sebesar Rp.1 maka Nilai Aktiva Bersih akan mengalami kenaikan sebesar Rp. 0,201 . Begitu juga sebaliknya, jika pertumbuhan Nilai Tukar Rupiah mengalami kenaikan sebesar Rp. 1 maka Nilai Aktiva Bersih akan mengalami penurunan sebesar Rp. 0,201.

e. Koefisien regresi PDB Perkapita bertanda negatif sebesar 1682,472 yang artinya jika variabel independen lainnya nilainya tetap dan perrtumbuhan

PDB Perkapita mengalami penurunan sebesar $1 \%$ maka Nilai Aktiva Bersih akan mengalami kenaikan sebesar Rp. 1682,472. Begitu juga sebaliknya, jika perrtumbuhan PDB Perkapita mengalami kenaikan 1\% maka Nilai Aktiva Bersih akan mengalami penurunan sebesar Rp. 1682,472.

f. Koefisien regresi Jumlah Uang Beredar bertanda positif sebesar 1,2290000000 yang artinya jika variabel independen lainnya nilainya tetap dan perrtumbuhan Jumlah Uang Beredar mengalami kenaikan sebesar Rp. 1 maka Nilai Aktiva Bersih akan mengalami kenaikan sebesar Rp.

1,2290000000. Begitu juga sebaliknya, jika perrtumbuhan Jumlah Uang Beredar mengalami penurunan sebesar $1 \%$ maka Nilai Aktiva Bersih akan mengalami penurunan sebesar Rp. 1,2290000000 . 


\subsection{Uji Hipotesis}

6.3.1 Ujit

Berdasarkan $\begin{array}{r}\text { hasil } \\ \text { analisis dengan }\end{array}$
menggunakan uji t, diketahui
bahwa pengaruh variabel-
variabel independen terhadap
variabel dependen adalah
sebagai berikut:

a. Variabel BI Rate mempunyai nilai signifikan sebesar 0,004 atau $0,4 \%$ yang artinya hipotesis diterima $(0,004<$ 0,05). Berarti secara parsial variabel BI Rate mempunyai pengaruh yang signifikan terhadap Permintaan Reksa Dana Saham.

b. Variabel Inflasi mempunyai nilai signifikan sebesar 0,743 atau $74,3 \%$ yang artinya hipotesis ditolak $(0,743>$ 0,05). Berarti secara parsial variabel Inflasi tidak mempunyai pengaruh yang signifikan terhadap Permintaan Reksa Dana Saham.

c. Variabel Nilai Tukar Rupiah mempunyai nilai signifikan sebesar 0,320 atau $32 \%$ yang artinya hipotesis ditolak $(0,320>$ 0,05). Berarti secara parsial variabel Nilai Tukar Rupiah tidak mempunyai pengaruh yang signifikan terhadap Permintaan Reksa Dana Saham.

d. Variabel PDB Perkapita mempunyai nilai signifikan sebesar 0,023 atau $2,3 \%$ yang artinya hipotesis diterima $(0,023<$ $0,05)$. Berarti secara parsial variabel PDB Perkapita mempunyai pengaruh yang signifikan terhadap Permintaan Reksa Dana Saham. e. Variabel Jumlah Uang Beredar mempunyai nilai signifikan sebesar 0,100 atau $10 \%$ yang artinya hipotesis ditolak $(0,100>$

0,05). Berarti secara parsial variabel Jumlah Uang Beredar tidak mempunyai pengaruh yang signifikan terhadap Permintaan Reksa Dana Saham.

\subsubsection{Uji F}

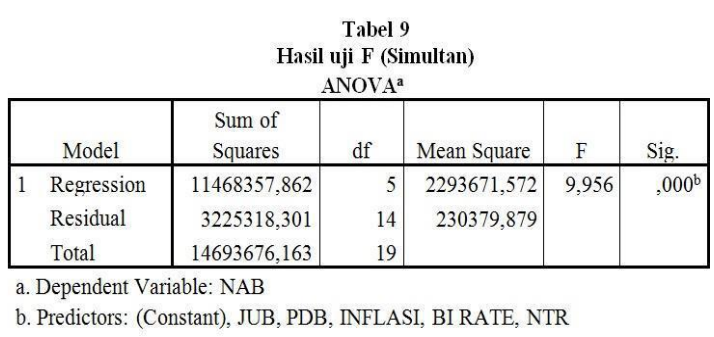

Dari hasil uji simultan dapat dilihat dri nilai signifikan $0,000<0,05$ maka hipotesis diterima (koefisien regresi signifikan). Dari uji ANOVA atau $\mathrm{F}$ test didapat niali $\mathrm{F}$ hituung sebesar 9,956 dengan probabilitas 0,000 . Karena probabilitas lebih kecil dari 0,05 maka model regresi dapat digunakan untuk memprediksi Nilai Aktiva Bersih atau dapat dikatakan bahwa variabel BI Rate, Inflasi, Nilai Tukar Rupiah, PDB Perkapita dan Jumlah Uang Beredar secara simultan berpengaruh terhadap Permintaan Reksa Dana Saham. 
6.4 Uji Koefisien Determinasi $\left(R^{2}\right)$

Tabel 6

Hasil Analisis Koefisien Determinasi

Model Summary ${ }^{b}$

\begin{tabular}{|l|c|r|r|c|}
\hline Model & \multicolumn{1}{|c|}{$\mathrm{R}$} & $\mathrm{R}$ Square & $\begin{array}{c}\text { Adjusted R } \\
\text { Square }\end{array}$ & $\begin{array}{c}\text { Std. Error of } \\
\text { the Estimate }\end{array}$ \\
\hline 1 &, $883^{\mathrm{a}}$ &, 780 &, 702 & 479,97904 \\
\hline
\end{tabular}
a. Predictors:(Constant), JUB, PDB, INFLASI, BI RATE, NTR
b. Dependent Variable: NAB

Dari perhitungan tabel diatas, dapat disimpukan nilai $\mathrm{R}^{2}$ sebesar 0,780. Artinya nilai koefisien determinasi sebesar $78 \%$ menunjukan besarnya proporsi keragaman total nilai-nilai variabel permintaan reksa dana saham yang dapat diterangkan melalui hubungan antara variabel BI Rate, Inflasi, Nilai Tukar Rupiah, PDB Perkapita, dan Jumlah Uang Beredar secara bersama-sama dengan probabilitas sebesar $78 \%$ menunjukan tingkat hubungan yang kuat, sedangkan sisanya sebesar $22 \%$ disebabkan oleh faktor-faktor lain yang tidak dapat dijelaskan.

\section{KESIMPULAN DAN SARAN}

7.1 Kesimpulan

a. Secara parsial variabel BI Rate mempunyai pengaruh negatif dan signifikan terhadap Permintaan Reksa Dana Saham.

b. Secara parsial variabel Inflasi mempunyai pengaruh positif dan tidak signifikan terhadap Permintaan Reksa Dana Saham.

c. Secara parsial variabel Nilai Tukar Rupiah mempunyai pengaruh negatif dan tidak signifikan terhadap Permintaan Reksa Dana Saham.

d. Secara parsial variabel PDB Perkapitamempunyai pengaruhnegatifdan signifikan terhadap Permintaan Reksa Dana Saham. e. Secara parsial variabel Jumlah Uang Beredar mempunyai pengaruh positif dan tidak signifikan terhadap Permintaan Reksa Dana Saham.

f. Secara simultan variabel BI Rate, Inflasi, Nilai Tukar Rupiah, PDB Perkapita dan Jumlah Uang Beredar memilikipengaruh signifikan terhadap Permintaan Reksa Dana Saham.

\subsection{Saran}

a. Investor dan manajer mempertimbangkan aspekaspek untuk memproyeksikan fluktuasi yang terjadi sehingga investor mendapatkan keuntungan dan memperkecil risiko. Penelitian ini diharapkan dapat memberikan acuan gambaran kepada investor dalam memilih prosuk reksa dana saham yang dapat memberikan hasil yang lebih baik.

b. Untuk pengembangan ilmu di bidang manajemen,

khususnya Manajemen Keuangan, sebaiknya untuk penelitianselanjutnya

menambahkan variabel mikro seperti penawaran dan faktor fundamental seperti pertumbuhan pendapatan dan return.

\section{DAFTAR PUSTAKA}

Filbert, Ryan, 2017. Menjadi Tambah Kaya dan Terencana dengan Reksa Dana, Jakarta: IKAPI Gramedia

Ghozali, Imam, 2016. Aplikasi Analisis Multivariate dengan Program IBM SPSS

23 Edisi 8. Semarang: Badan Penerbit UNDIP 
Hartono, Djogiyanto, 2017. Teori

Portofolio dan Analisis

Investasi,Yogyakarta: BPFE IKAPI.

Iswanto, Wilda Kusumah, 2017. Analisis Pengaruh Suku Bunga SBI, Inflasi dan Kurs Rupiah Terhadap Return Reksa Dana Saham, Jurnal Ilmu dan Riset Manajemen Volume 6, Nomor 3, Maret 2017.

Marsis, Adi Setiawan, 2013. Rahasia Terbesar Investasi Agar Kekayaan Anda Berkembang Lebih Cepat, Yogyakarta: Second Hope.

Maulana, Akbar, 2013 Pengaruh SBI, Jumlah Uang Beredar, Inflasi Terhadap Kinerja Reksa Dana Saham Di Indonesia Periode 2004-2012, Jurnal Ilmu Manajemen Volume 1 Nomor 3 Mei 2013.

Pasaribu, Rowland Bismark Fernando, 2014. Pengaruh Suku Bunga SBI, Tingkat Inflasi, IHSG dan Bursa Asing Terhadap Tingkat Pengembalian Reksa Dana Saham. Jurnal Akuntansi dan Manajemen Vol. 25, No. 1, April 2014:53-65

Singgih, Benny Prawira dan Leina Anna, 2015. Gini Caranya Dapat Untung Dari Bisnis Saham Dan Reksa Dana, Yogyakarta:CERTE POSSE

Sugiyono, 2017. Statistika untuk Penelitian, Bandung:Alfabeta Sukirno, Sadono, 2013. Makroekonomi Teori Pengantar Edisi Ketiga, Jakarta: Rajawali Pers.

Supranto, J, 2016. Statistika Teori dan Aplikasi Edisi 8 Jilid 2, Jakarta: Erlangga

Tandelilin, Eduardus, 2010. Portofolio dan Investasi, Yogyakarta:KANISIUS IKAPI.

Tim Penyusun, 2017. Modul Pelatihan Metedologi Penelitian, Fakultas Ekonomi Universitas Pancasakti Tegal
Umar, Akmal dan Nur Vadilah Putri, 2013. Analisis Pengaruh Variabel Makro Terhadap Permintaan Reksa Dana Saham di Indonesia Periode 20012011, Media Riset Bisnis \& Manajemen, Vol. 13 No,2 Agustus 2013

Widarjono, Agus, 2016. Ekonometrika

Pengantar dan Aplikasinya Edisi
Keempat, Yogyakarta:UPP STIM
PKPN

Sumber dari website :

bi.go.id, 2017

http://www.bi.go.id/id/moneter/transmisikebijakan/Contents/Default.aspx

Februari 2018)

http://www.bi.go.id/id/publikasi/perkemba ngan/Default.aspx (6 Februari 2018)

cermati.com, 2018.

https://www.cermati.com/artikel/investasireksa-dana-manfaat-

dan-risiko-yang-harus-dihindari (6

Februari 2018)

kompas.com.,2018.

http://ekonomi.kompas.com/read/2016/09/ 16/080000226/apa.dampak.kebijakan.suku .bunga.terhadap.kinerja.reksa.dana. (6 Februari 2018)

Merdeka.com, 2017.

https://googleweblight.com/?lite url=https ://m.merdeka.com/uang/bos-bei-sebutpenurunan-suku-bunga-bi-bikin-pasar$\underline{\text { modal- }}$

lebihmenarik.html\&ei=0QyeiseC\&lc=idID $\& \mathrm{~s}=1 \& \mathrm{~m}=726 \&$ host=www.google.com.hk $\&$ ts $=1519449094 \&$ sig $=$ AOyes_RrQGBPB 5stEJrtAjESH0oH6kxdxA

(6 Februari 2 018)

okexone.com, 2017.

https://googleweblight.com/?lite_url=https ://economy.okezone.com/read/2017/12/29/ 278/1837464/ke-bei-begini-kesangubernur-bi-terhadap-pasar-modalindonesia\&ei=Ry4ELKYq\&lc=idID\&s=1 $\& \mathrm{~m}=726 \&$ host $=\mathrm{www} \cdot$ google.com.hk\&ts= $1519449094 \&$ sig=AOyes_SyPtw0uTGfwhmX-AoMoBm6Ofpug (6 Februari 2018) 
wikipedia.org,2018.

https://id.m.wikipedia.org/wiki/Inflasi

$(6$

Februari 2018)

Rasyid, Irmala Sari, 2014.

http://irmalasarirasyeid.blogspot.co.id/201

4/10/bursa

efek-dan-pengaru/hnya-

terhadap.html?m=1
Rudiyanto, 2017. Apa Dampak Fluktuasi Nilai Tukar Rupiah Terhadap Kinerja Reksa Dana. Online.

http://rudiyanto.blog.kontan.co.id/2017/10 25/apa-dampak-fluktuasi-nilai-tukarrupiah-terhadap-kinerja-reksa-dana/.( 6 Februari 2018) 